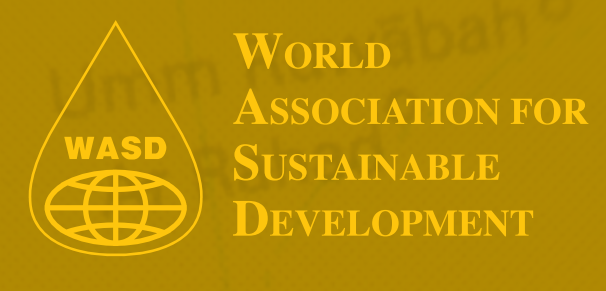

Elgilany A. Ahmed ${ }^{1}$

Universiti Utara Malaysia, Malaysia

and

Hamid H. M. Faki²

Agricultural Research Corporation, Sudan

\title{
Economics of main organic perennial food crops production and marketing in River Nile State of Sudan
}

1 School of Economics, Finance and Banking, College of Business, Universiti Utara Malaysia , 06010 UUM Sintok, Kedah Darul Aman, Email: elgilanya@yahoo.com

2 Agricultural Economics and Policy Research Center, Agricultural Research Corporation, Sudan, P. O. Box 30 Khartoum North, Shambat, Khartoum, Sudan, Email: hmfaki@yahoo.com 
Economics of main organic perennial food crops production and marketing in River Nile State of Sudan 


\section{Abstract}

Purpose This paper investigates the potential for growing organic perennial crops in the River Nile State (RNS). The production of these crops in the RNS faces numerous shortcomings, namely low level of productivity, high cost of production and inefficiency in resource use.

Methodology Beside secondary data, primary data were collected using structured questionnaires for fifty randomly selected respondents' tenants. Partial budgets were constructed for organic and conventional perennial crops. Linear Programming was used to model the optimal use of resources in perennial crops.

Findings The results showed that tenants would benefit from organic perennial production compared to conventional perennial crop production.

Value Therefore, they should be encouraged to establish organic perennial farms instead of the conventional ones and to be guided on how to grow organic products that give more advantages, better returns and contribute significantly to farm sustainability in the RNS.

Keywords production, marketing, organic perennial crops 


\section{Introduction}

Chang et al (2010) conclude that organic food, once a niche product for consumers seeking healthier and environmentally friendly alternatives to conventional food, has gained popularity and sales growth over the last decade. It is imperative that organic agriculture doesn't mean turning back the clock to a conventional mode of farming system, but it can use it as a base for promoting knowledge and practices. Furthermore, it offers a modern ecologically intensive farming system that can perform successfully without any synthetic chemical inputs (i.e. fertilizer, pesticides) to meet food security needs and poverty alleviation. Sudan has a great opportunity to take the lead in the production of organic food in both plant and livestock products. Unfortunately, the country is still lagging behind even in comparison with the African countries. The country possesses tremendous resources to produce different types of fruit trees some of them are ancient in the country while others were introduced not long ago. The most well-known fruit trees in Sudan include palm, banana, guava, citrus fruits and mangoes. By nature, perennials aren't as inflicting erosion- a growing problem in the country - as annual crops. Moreover, perennials simply grow by themselves after harvest, thus avoiding the relatively expensive sowing operation. They are grown in different regions of the Sudan and the River Nile (RNS) State is considered as one of main grower of perennial crops. In RNS perennial crops are regarded as essential food and cash crops within the prevailing cropping systems. They also play an important role in the sustainability of the farming systems through natural resources conservation and its good returns to investment with expanded cultivable area. The cultivated areas consist of a narrow fringe of land along the Nile covering about $124,000 \mathrm{~km} 2$ (29.5 million feddans) out of which about 3,201,300 feddans are suitable for agricultural production. A high population density exists in the settled areas along the River Nile and Atbara River with a total population of about 720,000 forming $90 \%$ of the State's population (Ahmed, 2009). Thus, most of the agricultural production depends on irrigation in areas close to the rivers. The climate is extremely dry with very hot temperatures from April to September and relatively cool from October to March. Along with the alluvial fertile soils, the conditions furnish a comparative advantages situation over other parts of the country in producing relatively high-value crops such as palm dates, citruses, mangoes, guava and alfalfa. While these are regarded as the most important perennial crops, wheat, legumes (faba beans, chickpeas, field beans, and lentils), vegetables, spices, sorghum and maize are the main annual crops in the RNS. Although the last decade witnessed development in RNS, the RNS still suffers from some chronic constraints affecting farm productivity and incomes such as high cost of production, inadequate finance, high marketing margins on agricultural produce and inadequate investments in infrastructures and other facilities. This has resulted in annual variations in areas of both perennial and field crops. Perennial crops are considered as strategic crops in the RNS occupying an estimated total area 120,000 feddans where they distributed over schemes of the RNS. The RNS is characterized 
by the prevalence of three types of schemes: private, cooperative and public schemes with different production relation systems. The public pump irrigated schemes are the important ones for growing perennial crops due to their high acreage share and high number of tenants. The delivery of the irrigation water for the scheme depends on pump irrigation system from the River Nile (RN), and the effectiveness of irrigation is determined by the availability and supply of fuel for water pumping and the degree of siltation in canals in public schemes. Elketiab public irrigated scheme, taken here as a case study, was established in 1917. The management of the scheme, as with the case of other public irrigation schemes of the Northern Region, was under the Northern Agricultural Production Corporation (NAPC). The total area of the scheme is about 12000 feddans, out of which 6200 feddans were cultivated in season 2005/2006. The area is distributed among 389 farms (hawasha) where perennial crops occupied about $71 \%$ of the total cultivated area, and the remaining portion was under the annual crops. The total number of tenants in the scheme is about 1687. At its start, Elketiab scheme adopted the crop sharing arrangement, which was later replaced by a water-rate system. The earlier-mentioned problems concerning perennial crops production in RNS are analyzed to see the effect of such constraints as high cost of production, inadequate credit, weak infrastructure and remoteness of the production region on the inadequate interaction with the rest of the country. The last three decades witnessed critical problems regarding the production of perennial crops. Constraints contributing to the low level and instability of perennial crop yields include poor application of technical packages, stress inflicted by the changing environmental conditions, especially temperature, beside widespread of different diseases, insects, pests, weeds and inadequate irrigation water. Ahmed (2004) stated that irrigation water significantly affects crop production in the State where the irrigated schemes suffer from irrigation shortage due to inadequate supply of irrigation inputs at the proper time and at the right prices. Finally, this study looks into option (s) to increase the productivity of perennial crops through increasing the efficiency of resources-use intensity in RNS's public irrigated schemes. More specifically, the research addresses the issue of organic perennial crops farms to enhance more incomes attainable by producers and to improve the agricultural environment. It also examines how organic farming system can contribute to the improvement of the performance of perennial crops. It is hypothesized that organic-perennials farms system in the RNS will benefit the tenants and improve farm sustainability. Success will depend on designing and establishing farmer-friendly environmental system of management that utilizes the limited resources appropriately in the public schemes in the RNS. Investment in organic perennial farms of the RNS, at least in its public irrigated schemes, might be instrumental in saving the environment and improving household standard of living.

\section{Objectives}

This paper looks at the later options, specifically to promote organic perennial crops production and marketing by optimizing the available agricultural resources of the agricultural sector in the State. Moreover, the research therefore seeks to address the issue of resources being used effectively to increase reliable income for producers; hence, to alleviate poverty. Success will depend on designing and establishing farmer-friendly systems of management that utilize the limited resources appropriately to stretch organic perennial crops area. This paper thus mainly 
aims to investigate the potentiality and feasibility of organic perennial crops by examining how organic farming system can contribute to the improvement of the performance of perennial crops in RNS. The study more specifically pursues to raise a more efficient use of expensive resources, through improvement of existing system in the RNS which might be able to save the available resources.

\section{Methodology}

The study was carried out in season 2005/2006 at Elketiab public irrigated scheme of RNS where perennial crops are commonly produced under pump irrigation mainly from the River Nile and to some extent from underground water. The farming system of the RNS is characterized mainly as not full-mechanized system. The perennial crops are considered the main cash crops in the tenancies system beside cereal and legume crops. Recently, the RNS enlarged animal production activities and oil crops. The sample size was 50 tenants, selected randomly, forming about $3 \%$ of the total tenants in the scheme. The sample size was determined according to the desired level of precision and availability of resources in terms of cost, time and other relevant facilities. Stratified random sampling proportional to size was used. Integrated analytical techniques comprising descriptive statistics, partial budgeting and linear programming (LP) are used to illustrate the potentiality and feasibility of organic perennial crops in the area of study. There are a number of tools that can be used to optimize resources use of the Linear Programming technique (LP) through the General Algebraic Modeling System (GAMS) program. Linear programming was used to conduct scenario analysis based on model solution to assess the optimally combining resources in prennial food crops in the crop combination through the change in value of the objective function (gross margin) and the allocation of the resources under study over the dominant crop combination. The following model was specified with gross margins maximization as the objective function:

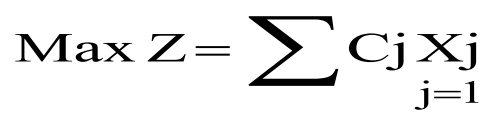

Such that:

$$
\sum \alpha i j X j \leq b i, \text { all }={ }_{j=1}^{n} \text { to } m
$$

And:

$$
\mathrm{Xj} \geq 0, \text { all } \mathrm{j}=1 \text { to } \mathrm{n}
$$

Where:

$Z$ = objective function value per year, $\mathrm{Xj}=$ Level of the jth the farm activity, such as the acreage of wheat grown. Let $\mathrm{n}$ denote the number of possible activities; the $j=1$ to $n$.

$\mathrm{Cj}=$ Objective value, in this case the forecasted feddan) gross margin of a unit of the jth activity (SDD per feddan)

aij = quantity of the ith resource available (i.e., days of labour or other required quantities of inputs) required to produce one unit of the jth activity $M=$ Denote the number of resources; then $\mathrm{i}=1$ to $\mathrm{m}$

$\mathrm{Bi}=$ Amount of the ith resource available (e.g. cubic meter of water, feddan of land, days of labour or other required quantities of inputs). 
The objective is to find the cropping system (defined as a set of activities levels $X j, j=1$ to $n$ ) that has the highest possible total gross margin, $Z$, but doesn't violate any of the fixed resource constraints or involve any negative activity levels.

Equation (1) is the objective function, which maximizes the gross margins from one feddan of prennial crops. Equation (2) shows the limits on the levels of the available resources (i.e., cubic meter of water, feddan of land, days of labour or other required quantities of inputs) that tenant can apply to produce the mentioned crops. Equation (3) which is a non-negativity condition, states that all resources used in the production process and output must be equal to or greater than zero i.e. negative use of resources and negative production is impossible. The coefficients represent the average requirement of the ith activity (enterprise), calculated on per feddan basis. The calculation of the crop water requirements (CWR) of any crop requires estimation of its crop coefficient $(\mathrm{Kc})$. Kc values could be used for estimation of CWR as a product of $\mathrm{Kc} *$ EToin for different regions of Sudan. Pen-man equation (1948) for calculating evapotranspiration from free water surfaces was used in the calculation of crop factors (CF by many scientists over the world. They were able to determine the CF of most filed and perennial crops in the world. Recently, Food and Agriculture Organization (FAO) Penman-Monteith (PM) method was developed to estimate ETo values from a hypothetical reference crop that were more consistent with the actual CWR and has been recommended by FAO as the standard method for CWR calculation. The reference crop evapotranspiration ETo was calculated from the daily whether data specifically the maximum and minimum temperature, relative humidity, wind speed at $2 \mathrm{~m}$ height and sunshine duration by using
Crop Wat4 windows program according to the recommended Penman- Monteith formula as shown in Equation (4).

$$
\text { ETo }=C(W R n+(1-W) f(u)(\text { ea-ed })
$$

Where:

$$
\begin{aligned}
& C=\text { error factor } \\
& W=\text { weighting factors } \\
& R n=\text { net radiation } \\
& f(u)=\text { function in wind speed } \\
& \text { ea }=\text { saturation pressure } \\
& \text { ed }=\text { perfumed water }
\end{aligned}
$$

The data used to calculate gross returns per feddan are output value (crop prices times' quantity of output, i.e. yield per feddan), while gross margin per feddan is obtained by subtracting the average total variable cost from the total returns. Gross margins reveals how much a firm (farm, company etc.) earns taking into consideration the costs that it incurs for producing its products and/or services and it could be expressed as a percentage. Gross margin is a good indicator of how profitable a firm is at the most fundamental level. Farms with higher gross margins will have more money left over to spend on other activities such as investment, improvement of production and marketing.

Equation (5) is the general mathematical form for the gross margin calculation per crop is as follow:

$\mathrm{GM}=\mathrm{GR}-\mathrm{TVC}$

Where:

$\mathrm{GM}=$ Crop gross margin per fed in SDD, $\mathrm{GR}=$ Crop gross revenue per fed in SDD and GM = TVC: Crop total variable costs per fed in SDD. 


\section{Result and discussion}

This section initiates the main socioeconomic indicators in Elketiab scheme; the average age of the respondents is 50 years, while the average family size is 10 persons. The tenants are characterized by a high cumulative farming experience averaging 32 years. The average farm size in the scheme varies from 1 to 27 feddans per household farm 'Hwasha', with most of the farms $(64 \%)$ on rent basis. The farming system of Elketiab scheme is dominated by citruses production which accounts for $53 \%$ of the farm land. The level of education, at a certain point, can influence the adoption of modern technologies and improve the farm system. The study found that all the surveyed tenants are educated and all of them were male. As high as $76 \%$ of the tenants were fully occupied with their tenancies and about $82 \%$ of their family members contributed to farm production with an average of two persons.

Production of organic perennial crops in RNS.

Recent trends in supermarkets offering healthier and natural food choices can be seen as a reaction to consumer concerns. The rapid expansion in the organic food market has triggered growth in the organic milk industry Alviola and Capps (2010).

Saitone and Sexton (2010) reported that governments in many countries allow producers in agricultural industries to self-regulate, although the form of such regulation, including the extent of government oversight, varies considerably by country.

The situation of organic agriculture is summarized by Taher (2003) that traditional production system in Sudan is close to compliance with EC-regulations 2092/91. They can be qualified as non-certified organic products as their use of chemicals is not common because of high cost or unavailability. There are three projects under certification: one is in Gadarif, the second in Sennar state and the third is in North Kordofan. The project in North Kordofan is based on large groups of small holders working privately and supervised by Organic Products Company (joint venture Company between CEDAR Co. and OTTER Co. - Dutch trading company) which started its activity at the beginning of 2001. The Organic Products Company is the largest exporter of organic products from Sudan. There are other companies that export organic products from wild sources. Markets are mostly European countries. Certification bodies working in Sudan are: ECOCERT, COAE, and ECOA. Potentials of stretching organic agriculture in Sudan are great. Large areas are cultivated without synthetic chemical inputs and can be easily converted into certified organic areas. Sudan has got enormous potentiality for producing organic foods. This is attributed to the huge natural resources and the wide range of biodiversity available with high relative advantages, which justify its lead in organic food production Taher (2003). The production of these crops is based on a fixed water rate system i.e. the scheme administration responsible to supply irrigation water and the tenants pay the water value per watering. In this area of study there are numerous factors that qualify the scheme to take comparative advan 
tage in producing perennial crops such as favorable climatic conditions, vast endowments (i.e. land and the permanent sources of irrigation), and accumulative experiences of skilled farmers. Although the scheme is characterized by the earlier mentioned criteria, the last decade witnessed frequent debates about the deterioration of agricultural production. There are various reasons for those deteriorations namely, low crop productivity, high cost of production, inadequate credit and marketing and prices instability. The option of irrigation is mandatory in the scheme from the River Nile by pumps, as well as a little amount from ground water for supplementary irrigation. The study found the perennial crops in the River Nile district occupied only about $16 \%$ of the total cultivated area in 2006, while the prevalent perennial crop combination consist citruses, date palms, mangoes, guava and alfalfa (see Figure1).

The research unveiled that the land devoted to perennial crops in the scheme was up to $53 \%$ occupied by citruses, followed by $15 \%$ for alfalfa, while date palms and guava were formed $13 \%$ and $11 \%$, respectively. The lowest percentage $(1 \%)$ was formed by mangoes as depicted in Figure (1).

The paper also analyzed the land allocation at the tenancies level. It revealed that that citruses percentage share was $58 \%$ of respondent farmers' tenancies as the highest percentage over the perennial crop combination, while mangoes were the lowest one (see Table 1).

Figure 1. Prevailing perennial crop combination in area of the study

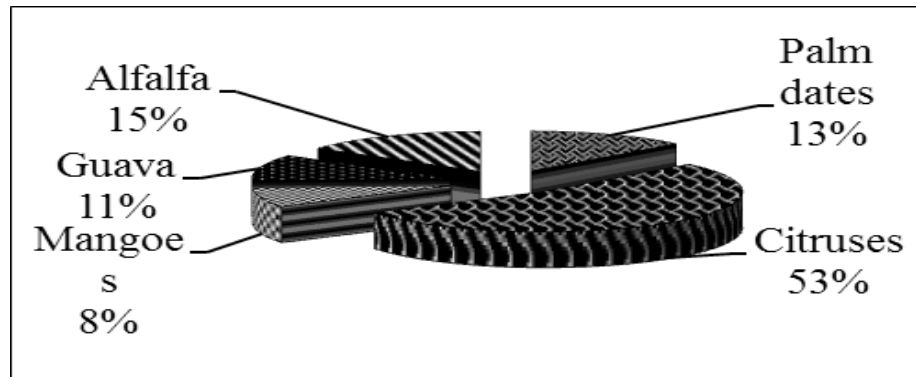

Table 1. Distribution of tenants according to area and production of crops

\begin{tabular}{|c|c|c|c|}
\hline Crop & Area & Production & $\begin{array}{l}\text { Crop share of } \\
\text { farm area }\end{array}$ \\
\hline & (fed) & (kg) & $(\%)$ \\
\hline Dates & 1.23 & 3690 & 14 \\
\hline Citruses & 5.01 & 17535 & 58 \\
\hline Mangoes & 0.75 & 1219 & 8 \\
\hline Guava & 1 & 1050 & 11 \\
\hline Alfalfa & 1.43 & 8875 & 15 \\
\hline
\end{tabular}


The conventional perennial crop yields achieved by Elketiab surveyed tenants were generally low when compared by research yields attained by the Agricultural Research Corporation (ARC) of the country and the conventional perennial's yields, with minimum and maximum yield gap reaching $74 \%$ and $26 \%$ for date palms and alfalfa, respectively, while the organic perennial crops yields obtained in research were lower than both conventional and research conventional perennial's yields as shown in Table (2). The results indicate that there is high potential to increase yields of all organic and conventional perennial crops under study. However, the average organic crop yields are often lower than the average conventional yields. Yield differences reflect not only different farming practices but differences in experience. The organic industry is expanding so rapidly that many organic farmers are relatively inexperienced with organic methods.

Stonehouse (2000) reported that the most challenging time is the transition period as farmers switch from conventional to organic agriculture. During this period, the price premium is absent and yields are low. Sometimes farmers can receive a minor price premium for transitional production, with a price higher than conventional prices, but lower than the certified organic prices. During the early stages of conversion, some farmers have reported drops in yields of up to $30 \%$. Later, yields tend to increase with the number of years under organic management as farmers gain experience and the soil improves (see Figure 2). In Africa, conversion to organic agriculture was estimated to increase productivity by 56 percent by 2030 (Badgley et al., 2006).

Table 2. Distribution of disposal of perennials quantities in the scheme

\begin{tabular}{|c|c|c|c|c|}
\hline Crop & Production & $\begin{array}{c}\text { After harvest } \\
\text { sale }\end{array}$ & $\begin{array}{c}\text { H.H } \\
\text { consumption }\end{array}$ & Future sale \\
\hline & (kg/farm) & $(\%)$ & $(\%)$ & $(\%)$ \\
\hline Date & 3690 & 55 & 15 & 30 \\
\hline Citrus & 37900 & 90 & 2 & 8 \\
\hline Mango & 1163 & 85 & 15 & - \\
\hline Guava & 1050 & 80 & 20 & - \\
\hline Alfalfa & 8568 & 19 & 81 & - \\
\hline
\end{tabular}


Figure 2. Yield gaps of conventional and organic perennials compared to ARC

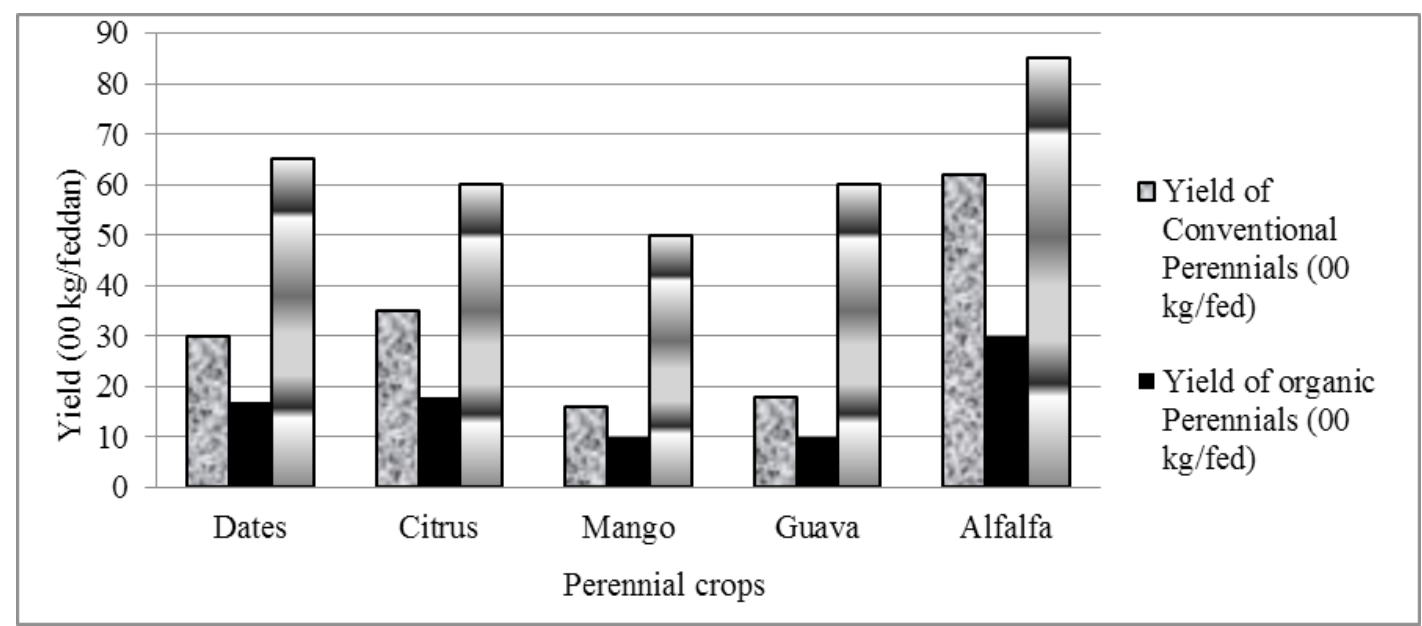

Cost of production for organic and conventional perennial food crops

Production economics play a unique role in farm management (Doll and Orazem, 1984). Organic farming practices can cut production costs as well, according to OCO (2008) that after compensating for an additional ninehour per acre labor expense, the organic rotation showed a savings of $\$ 66 /$ acre in input expenses. At an average of $\$ 250 /$ acre machinery expense, the smaller farm saves $\$ 93,500$ in machinery investment over the conventionally managed farm. The dominant conception of production cost in the area of study is known as the cost of material inputs, labor, services, and the management used in producing a certain goods and/or crops. Many studies showed that the overall cost of production in the RNS has led to low profit. The high cost of production is attributed to high cost of numerous production inputs. The RNS farmers complain from high cost of production and they depend on their resources totally for financing their perennial crops by about 600 SDG/fed indicating that the formal financial system was absent. Ijami (1994) mentioned that the formal financial system provides only small parts of credit used by farmers. Therefore, most of farmers seek other informal sources of finance. Loans extended by friends and relatives, mostly without interest, constitute the non-commercial segment. In the commercial segment a range of people like traders, agricultural and professional money lenders operate. Figure (3) reveals that about 12 main cost components constitute the cost of production for perennial crops.

Figure 3. Percentage share of operation cost components for Elketiab perennials

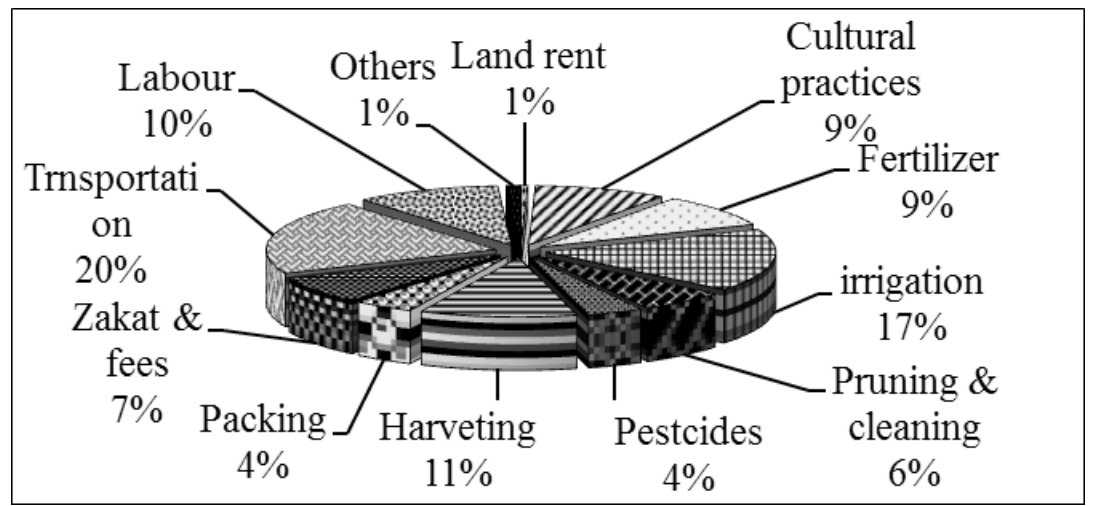


Figure (3) revealed that transportation cost component is absolutely considered as the most agricultural hindrance facing perennial crops production, having the highest cost item at $20 \%$ of total production cost. This might refer to the inadequate investments in infrastructure. This is followed by the irrigation water cost, which is also regarded as one of the most important agricultural constraints that is caused by the high cost of water pumping; and justifies the need for strict allocation among the different crops grown. The perennials growers in Elketiab scheme pay the cost of this item as a fixed rate for the scheme administration at the end of the year. The following elaboration of the survey results in Figure (3) shows the cost components in terms of conventional and organic perennial crop production operations, while Figure (4) illustrates the variation in production cost for organic and conventional perennials. Figure (4) shows that all organic perennial crops under study have lower costs of production than conventional ones, with much less emphasis on purchased inputs. Synthetic fertilizer and pesticide purchases are eliminated.
In addition, organic farmers have lower fixed (overhead) costs for depreciation and interest charges attached to capital inputs, such as machinery and equipment (e.g. knapsack sprayers and the like). Further, input costs are lower on organic perennial crops. Organic perennials farming methods replace herbicides with mechanical cultivation and other management practices to provide weed control. Generally, many studies mentioned that in organic agriculture systems, purchased input costs tend to be $40 \%$ lower while less irrigation water is needed. Furthermore, organic agriculture could give smallholder farmers the chance to access lucrative commercial markets for organic produce, on condition of course that affordable certification procedures and trading partnerships are established. While certified organic agriculture offers market competitiveness, non-certified organic systems offer advantages for subsistence agriculture, especially in areas where inputs are not available and labour is abundant. In both cases, agro-ecological knowledge is a precondition, posing the challenge of establishing adequate extension systems.

Figure 4. Variation in production cost for organic and conventional perennials

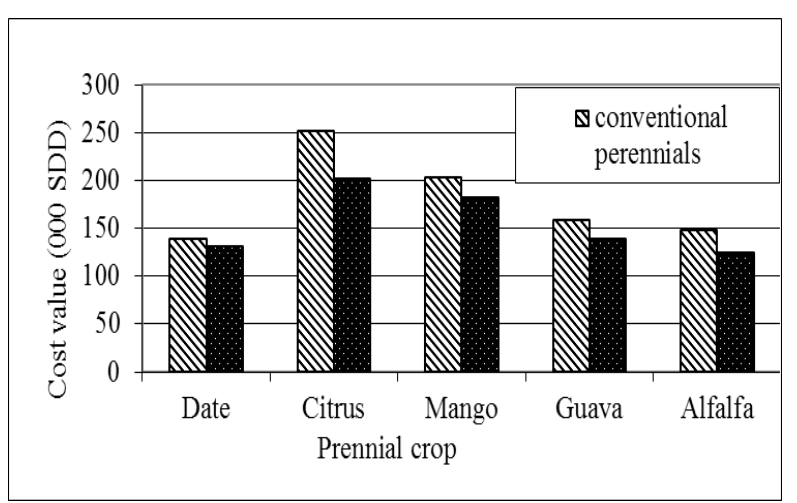




\section{Marketing of conventional and organic perennial crops in the State}

Trade in organic products is a new area whereby Sudan can realize additional export earnings and enhance farm incomes, food security and rural development. Estimated at 10-12 billion US\$ annually, trade in organic products worldwide is increasing rapidly. It is estimated to reach 80 billion US $\$$ by 2008. Most of Sudanese commodities are free from chemical contamination and could be sold as organic products provided the necessary infrastructure and procedures are put in place (Adam, 2008). The world organic market is growing at a rate of 20 percent per year. It is a clear fact that organically grown food in Sudan will have a wideopen door in the international market reaching much higher prices and consequently more national revenue. Farmers cultivating those food products will also get more income, which will be positively reflected on their standard of living. More national revenue means more money available for solving pertaining problems hindering Rural Development. Marketing such large amounts of organic foods will make Sudan a prominent figure in the international market of these products. It will also attract global investors to agricultural production of such crops (Babiker, 2003). Over the last decade RNS witnessed improvement in crop marketing due to some progress in road infrastructure. Although there are numerous linkages and options for marketing of perennials' products, tenants still face some difficulties to take the right decision of where and when to make their sales. The hesitancy of RNS tenants might be attributed to the high cost and difficulties of transportation, which forms the highest marketing cost item, in addition to the fees along the roads for accessing big city markets. Furthermore, lack of some marketing infrastructures, such as cold storage, are considered as chronic hindrances facing perennials producers in Elketiab. This situation compels small tenants to sell their produce immediately after harvest at very low farm gate prices for big farmers or traders. The study revealed that more than $50 \%$ of Elketiab tenants prefer to sell their crops in nearby markets, while $46 \%$ of them take their crops to Khartoum state markets, which are about $250 \mathrm{~km}$ away. It is observed from this research that the means of communication became essential in the area of study where they play an important role in reducing marketing cost and, to some extent, in raising farmers' awareness about urban markets. The tenants in the area of the study reported that they depend on mixed sources of market information such as market centers, wholesalers and the agricultural office of the scheme.

Based on this fact, RNS will need to establish its organic perennial production considering international options of this industry and gradually follow a robust plan to pursue successive amendments. This would enable the RNS products to be exported as organic. However, the existing non-compliance with the strict standards and specifications would require considerable time and resources before the RNS can enter the international market of organic perennial products. Adam (2008) summarized that trade in organic products is handicapped by many constraints, including: (1) Absence of a national organizing body to oversee the whole range of issues of the supply chain, (2) Lack of awareness of farmers of the opportunities in international markets, (3) Low productivity and high costs of production due to lack of improved technology, weak extension services and lack of finance, and (4) Poor infrastructure and inadequate marketing system. 
Contribution of perennial crops in household food security and income

The certified organic lands area in Sudan is estimated at 200,000 hectare and 650 farms, accommodating different crops such as tropical fruits, groundnuts, but also cotton, herbs/ spices and others (Lim, 2007). Perennial crops are important sources of household food security and nutrition in both the humid and semi-arid tropics, besides being regarded as essential cash crops. They can yield as much food per feddan as most annual crops. They also offer great ecological and social benefits, and they can thus be productive and/or protective. Although RNS farmers exert tremendous efforts all over the growing seasons and dream of a successful harvest, they end up disappointed by unfavorable prices. Given limited infrastructure, this leads to the quick sales mentioned earlier, but they nevertheless distribute the disposal of part of their produce over the remaining part of the season as shown in Table (3).
Decisions on marketable surplus quantities either to be sold immediately after harvest and/or for future sale depends on the crop perishability after devoting a certain amount for household consumption as depicted in Table (3). The surveyed farmers reported that only two crops could be kept for future sale, namely palm dates and citruses. Elketiab farmers store citruses on trees for 3-5 months after maturity and they sell them when prices improve. It is derived that $2214 \mathrm{~kg}$ of dates and $3778 \mathrm{~kg}$ of citruses production are allocated either for storage or future sales. Also $81 \%$ of alfalfa production is considered for household-animal consumption while the rest is regarded as marketable surplus. For the other crops (mangoes and guava) the produce usually goes to market after devoting some quantities for household consumption as shown in Table (3).

Table 3. Distribution of disposal of perennials quantities in the scheme

\begin{tabular}{ccccc} 
Crop & Production & $\begin{array}{c}\text { After harvest } \\
\text { sale }\end{array}$ & $\begin{array}{c}\text { H.H } \\
\text { consumption }\end{array}$ & Future sale \\
\hline Date & 3690 & $(\%)$ & $(\%)$ & 30 \\
\hline Citrus & 37900 & 55 & 15 & 8 \\
\hline Mango & 1163 & 90 & 2 & - \\
Guava & 1050 & 85 & 15 & - \\
\hline Alfalfa & 8568 & 19 & 81 & - \\
\hline
\end{tabular}


While the expected contribution of organic perennials to household nutrient intake can be promoted by diversifying and optimizing farm productivity, reducing the need for purchased inputs and, eventually, developing households market-orientation for earning additional income, will be conducive to organic systems contributing to hunger and poverty alleviation. According to Stonehouse (2000), every 10 percent increase in crop yield reduces the number of income-poor by an average 7.2 percent in sub-Saharan Africa. Improved income allows farmers to buy food in what would otherwise be hungry months. Harnessing the lucrative gains that come from marketing organic commodities can allow seasonal or permanent diversification away from staples into high-value alternatives such as vegetables, depending on the degree of physical and human capital investment and agro-ecosystem flexibility. Numerous studies reported that although in most cases, staple food systems will remain dominant sources of food supply and off-farm activ ities are more dependable sources of income, organic diversification offers higher returns from land and labour investments. However, the diversification start-up is often associated with high-price volatility which needs to be countered with improved marketing intelligence.

\section{Income sources of the surveyed tenants}

Most of the farm studies confirmed that diversifying income sources opportunities might enhance farm sustainability. The most common source of tenants' income is the sale of produced crops and livestock and other products raised or bought for resale. Off-farm income is still one of the principal options for Elketiab tenants to meet their farm and household expenditures. The main offfarm sources in study area are mainly remittances and contributions of the family members, formal employment, trade, and other off-farm private activities as portrayed in Table (4).

Table 4. Farm and off-farm income sources of tenants

\begin{tabular}{|c|c|c|c|c|}
\hline Source of income & Value & $\begin{array}{c}\text { After } \\
\text { harvest } \\
\text { sale }\end{array}$ & $\begin{array}{l}\text { H.H } \\
\text { consumption }\end{array}$ & $\begin{array}{l}\text { Future } \\
\text { sale }\end{array}$ \\
\hline & $\begin{array}{l}\text { Farm in- } \\
\text { come }\end{array}$ & $\begin{array}{c}\text { income of } \\
\text { Total }\end{array}$ & Tenants & $(\%)$ \\
\hline & (SDD) & $(\%)$ & $(\%)$ & $(\%)$ \\
\hline Perennial crops returns & 1870280 & 78 & - & - \\
\hline Seasonal crops returns & 396533 & 17 & - & - \\
\hline Livestock returns & 107059 & 05 & - & - \\
\hline $\begin{array}{l}\text { Total average of in- } \\
\text { farm income }\end{array}$ & 2373872 & 100 & 82 & 32 \\
\hline $\begin{array}{l}\text { Total average of off- } \\
\text { farm income }\end{array}$ & 522700 & - & 18 & 68 \\
\hline $\begin{array}{c}\text { Total average income of } \\
\text { tenants }\end{array}$ & 2896572 & - & 100 & 100 \\
\hline
\end{tabular}


The results of Table (4) reveal that $68 \%$ of Elketiab tenants earned offfarm income beside their farm income, while $32 \%$ of the total surveyed tenants relied only on farm returns from their main sources of activities as depicted in Figure (5).

Figure (5) also shows that farm income accrues mainly from three sources: perennial crops providing the highest farm returns $(78 \%)$ followed by annual crops $(17 \%)$, and $5 \%$ from livestock as the lowest one. This confirms the importance of perennials in shaping the tenants' income in the area of study. In case of organic producing farmers, the majority diversify their businesses by growing several crops at one time, often having both livestock and field crops, and sometimes value-adding enterprises as well. The diversification reduces economic risks. As well, enterprise diversification makes it easier for farms to be more self-sufficient in terms of nutrients, livestock feed, soil organic matter and energy. Many experienced organic farmers have crop yields as high as, or higher than, the average conventional yields.

\section{Analysis of conventional and organic perennials returns}

Since organic farming is feasible in the agricultural sub-sector, the aim should be its dissemination in the country and maximization of organic production. Partial budgeting methods continue to be the backbone of much of analysis on agricultural policy. In their simplest form, budgets provide the evidence that policy makers use to make decisions about private profitability and hence the incentives that farmers have to grow particular commodities. The basic data used to calculate gross returns per feddan are output value (crop prices times' quantity of output, i.e. yield per feddan) from which average total variable cost are deducted to get gross margin per feddan.

\section{Gross margins}

Gross margins reveal how much a firm (farm, company etc.) earns to pay for its fixed costs. Gross margin is a good indicator of how profitable a firm is at the most fundamental level. Farms with higher gross margins will have more money left over to spend on other activities such as investment, improvement of production and marketing (see Equation 5).

The last decade witnessed that the global demand for organic foods is annually increasing due to consumers' awareness of their value and benefits. Babiker (2003) reported that, Sudan exported 20 plant and livestock food products as conventionally cultivated foods valued at US\$305.7 million. An internet survey for international prices of some organically produced agricultural foods revealed that the difference in price between conventionally and organically produced foods ranges between $38 \%-120 \%$, with an average of $79 \%$ increase. This percentage increase in price would be applicable to Sudan agricultural exports if those products were marketed as organic foods. Then they would have obtained total national revenue of US\$ 547.2 million, i.e.

Figure 5. Sources of farm income for Elketiab surveyed tenants

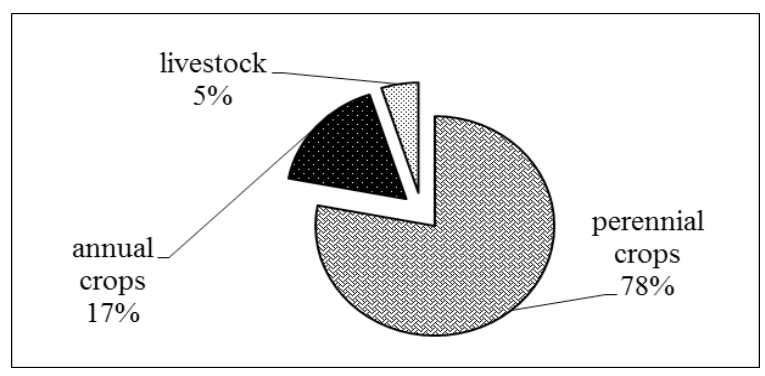


an increase of US\$241.5 million. In fact those agricultural food products were organically grown but not officially certified by any internationally recognized organization accredited with such certification. The gross margins for conventional and organic perennial crops under study also were assessed individually per feddan and the results were expressed in Sudanese Dinar (SDD) as discerned in Table (5a) and Table (5b).

Tables $5 \mathrm{a}$ and $5 \mathrm{~b}$ illustrate that gross margins of both conventional and organic perennial crops were positive, but organic perennial crops enjoyed higher gross margins. The high returns applicable to organic perennials compensate for their low yields, and with yield improvement of organic perennials, still higher gross margins can be obtained. In general, expenses are lower and the income is greater (due to the price premium). Price premiums vary between crops and over time. On the other hand organic production is changing rapidly, leading to price instability. For example, a high premium price for one crop can lead many tenants to grow that crop, which might depress prices. Thus tenants' awareness is needed about marketing issues within the promise offered by organic farming.

Table 5a. Gross margin analysis for conventional perennial crops (SDD/fed)

\begin{tabular}{lllllll}
\hline \multicolumn{1}{c}{ components } & Date & Citruses & Mangoes & Guava & Alfalfa \\
\hline \multicolumn{2}{l}{ Production cost (SDD/fed) } & 139224 & 251704 & 203120 & 158506 & 147549 \\
Average yield & $(\mathrm{kg} / \mathrm{fed})$ & 3000 & 3500 & 1625 & 1800 & 6206 \\
Average price & $(\mathrm{SDD} / \mathrm{kg})$ & 48 & 80 & 150 & 110 & 26 \\
Gross returns & $(\mathrm{SDD} / \mathrm{fed})$ & 144000 & 280000 & 243750 & 198000 & 161356 \\
Gross marginal & $(\mathrm{SDD} / \mathrm{fed})$ & 4776 & 28296 & 40630 & 39494 & 13807 \\
\hline
\end{tabular}

Table 5b. Gross margin analysis for organic perennial crops (SDD/fed)

\begin{tabular}{lllllll}
\hline \multicolumn{1}{l}{ components } & \multicolumn{1}{c}{ crops } & Date & Citruses & Mangoes & Guava & Alfalfa \\
\hline \multicolumn{2}{l}{ Production cost $(\mathrm{SDD} / \mathrm{fed})$} & 131197 & 202299 & 181537 & 138506 & 124870 \\
Average yield & $(\mathrm{kg} / \mathrm{fed})$ & 1700 & 1800 & 900 & 1000 & 3000 \\
Average price & $(\mathrm{SDD} / \mathrm{kg})$ & 86 & 142 & 278 & 190 & 48 \\
Gross returns & $(\mathrm{SDD} / \mathrm{fed})$ & 146200 & 255600 & 250200 & 190000 & 144000 \\
Gross marginal & $(\mathrm{SDD} / \mathrm{fed})$ & 15003 & 53301 & 68663 & 51494 & 19130 \\
\hline
\end{tabular}


The results also revealed that, the gross margins from mangoes was the highest one, followed by guava, citruses and alfalfa for both conventional and organic perennials, while the gross margin of both conventional and organic date palms was the lowest (Figure $6)$.

\section{Optimal perennials production obtained by RNS model}

Secured land and water-use rights are more important preconditions for investments in organic diversification and commercialization than for other forms of agriculture. Organic background of RNS tenants for growing conventional perennials, annual crops and animal breeding offer a promising option for improving the farm system and livelihood of people both in rural and peri-urban areas. The competition for irrigation water and land increases resource management complexity. These inputs constitute the most important factors of agriculture in the River Nile State, due to their scarcity and importance raised from population pressure on land when compared to the rest of the country and from the high cost of irrigation by pumps. Those issues became common problems that was aggravated even more by the diminution of the canals capacities and eventually led to low productivity of crops. Elsir et al (2004) summarized that the high cost of production coupled with low productivity and lack of a cheap source of power has made it difficult for farmers to realize the full potential of the RNS. Further, development is considered seriously affected by the limitation of these two basic resources of land and water.

This situation led to an important fact that optimizing of the available resources should achieve food security, poverty alleviation and improve the livelihood of the farmers of the scheme. Yet, the potential of resources for raising both food production and living standards of the rural poor has since long been recognized. Generally, a third of the current crop production comes from one-sixth of the irrigated arable land. This necessitates improved reliability of crop production under greater intensity of land-use with removal of seasonal water supply constraints. The challenge would be how to balance demand and supply of resources under these conditions, which could be dealt with through resources optimization. The information received from the model run is the objective function value (returns), the optimal crop combination, and utilized resources accompanied by their respective marginal value productivities. The analysis also provided some other relevant results as shown in Table 6.

Figure 6. Gross margins of organic and conventional perennial crops

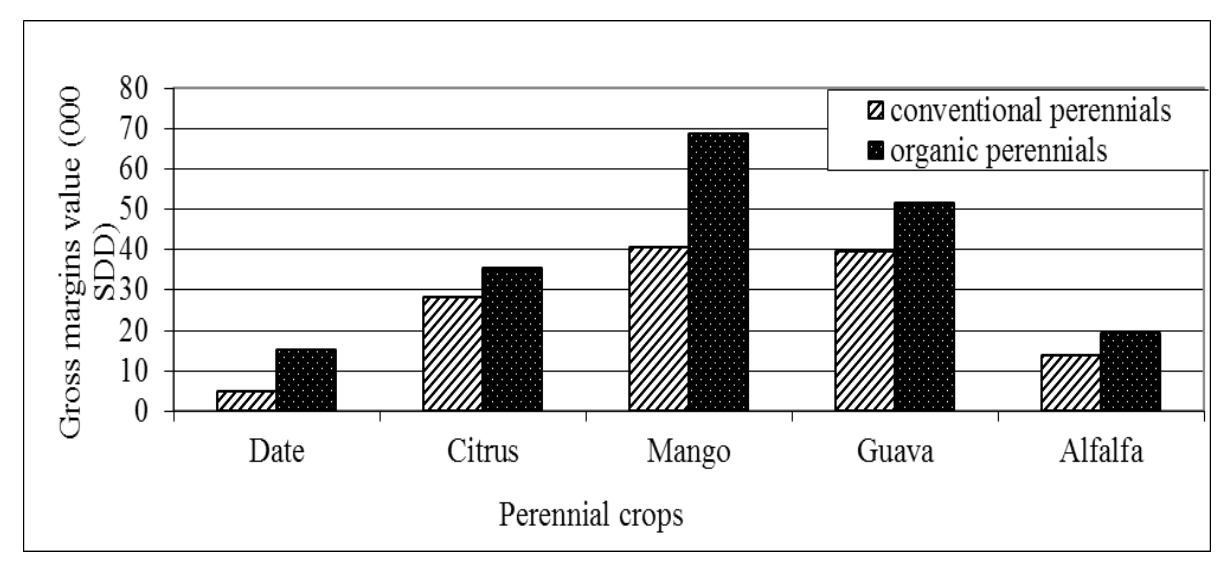


Table 6. Proposed scenario of cropping pattern plan for organic and conventional perennial crops in RNS

\begin{tabular}{|c|c|c|c|}
\hline Item & Actual & Optimal & Units \\
\hline \multicolumn{4}{|l|}{ Resources use: } \\
\hline Total land & 10 & 10 & Fed \\
\hline Total irrigation water & 131256 & 122976 & $\begin{array}{c}\text { Cubic meter } \\
\text { (m3) }\end{array}$ \\
\hline Total labour & 106 & 84 & Man-day \\
\hline Total capital & 1675200 & 1675200 & SDD \\
\hline \multicolumn{4}{|l|}{ Cropping pattern: } \\
\hline Conventional Date & 1 & - & Fed \\
\hline Conventional Citrus & 1 & - & Fed \\
\hline Conventional Mango & 1 & - & Fed \\
\hline Conventional Guava & 1 & - & Fed \\
\hline Conventional Alfalfa & 1 & - & Fed \\
\hline Organic Date & 1 & - & Fed \\
\hline Organic Citrus & 1 & 4 & Fed \\
\hline Organic Mango & 1 & 2 & Fed \\
\hline Organic Guava & 1 & - & Fed \\
\hline Organic Alfalfa & 1 & 4 & Fed \\
\hline
\end{tabular}


Table 6 also presents the actual and optimal cultivated area for the different perennial crops and provides the optimal allocation for the average area. The farmer's trend in RNS towards diverse crop combination is a dominant practice as a means of increasing efficiency of resources. This behavior might be acquired by experience to avoid agricultural risks such as pests and unfavorable climatic conditions (i.e. high temperature, low moisture and others). The optimal solution reflects devoting land only for citruses, mangoes and alfalfa as 4, 2, and 4 fed respectively, while the rest of the crops didn't appear in the optimal plan. The actual returns from crop production are SDD 134998, while the optimal returns are SDD 427050 which is more than the actual returns by $68 \%$.

\section{Resource use and constraints}

The last decade witnessed increased interest in growing perennial crops at the RNS, and that might be due to the higher prices or the low operation costs of those crops when compared to the annual crops according to their duration on land. Many studies mentioned that the higher prices for perennial crops have enhanced incentives to grow them. Moreover, growing of perennial crops allows intercropping with some crops, particularly alfalfa. According to the mentioned characteristics of the perennial crops, resources use and availability might be under competition. Stan (2008) stated that perennial plants are highly efficient and responsive micromanagers of soil, nutrients, and water. On the other hand, annual crops require churning of the soil, precisely timed inputs and management, and favorable weather at just the right time. With shorter growing seasons and ephemeral, often small root systems, annual crops provide less protection against soil erosion, wasting water and nutrients, storing less carbon below ground, and are less tolerant to pests than are perennial plant communities (Table 6).

From Table (6), the optimal and actual quantities of capital used for the different perennial crops under the study are SDD 1675200 and SDD 1675200. It is clear that the optimal plan resulted in all available land and cash to be devoted to organic perennial crops (citruses, mangoes and alfalfa), while the optimal and actual water used are $122976 \mathrm{m3}$ and $131256 \mathrm{~m} 3$ respectively. The optimal level of hired labour amounted to 84 , forming $79 \%$ of the total available labour. In the optimal plan, $122976 \mathrm{~m} 3$ of the total water would be used, which is $94 \%$ of total available water.

The monthly distribution of labour in the optimal plan is 7 man-days, forming $78 \%$ of total available labour. At the optimal crop combination, the monthly distribution of actual available cash to finance the perennial crops was SDD 13960 allocated annually over the months, forming $100 \%$ of the total available capital. 


\section{Conclusions and policy implications}

Our results show that there are promising opportunities for the production of organic perennials in River Nile State of North Sudan . However, a major obstacle to expanding and realizing the potential of perennial crops is the high cost of establishing new plantations and the recurrent cost of financing crops for four to five years before any significant production can be realized. Finance provision for these crops is absent in the area of study. The study unveils the low productivity of the organic perennial crops that form promising strategic crops. Encouraging policies imply reducing the cost of production or providing incentives to the organic perennials growers of the RNS by buying their products at reasonable prices. Based on these facts and the obtained results, the study concludes that:

- The potential for organic perennial farms production in the RNS is quite promising on account of the huge natural resources and the wide range of biodiversity available with high relative advantages.

- Establishment of organizing and certification bodies and development of national regulation for certified organic perennial crops production, handling, processing and marketing can be useful for implementation and sustainability of organic perennial farms in the RNS.

- Encouragement of some international companies with good history and long experience in production and marketing of proposed organic products to shoulder the responsibility and foster organic agriculture in the State.

- Because basic services are regarded as one of the chronic constraint facing agricultural production in area of the study, intervention is needed to establish infrastructures (i.e., roads, stores, processing stations).

- Spreading organic perennial culture among producers, processors and exporters of RNS is important. Also extension will be of fundamental importance to build agro-ecological knowledge. The fact that organic agriculture emphasizes multi-cropping, rather than mono-cropping is also important in terms of food security, which can be jeopardized when farmers produce a single commodity and have no safety net to fall back on.

- Relevant stakeholders' interventions are needed to transfer improved technologies to increase farm productivity. In addition, the RNS tenants also need to be encouraged to produce organic perennial crops as high value crops when designing crop combination.

- Improving finance institutions will enable the RNS tenants to improve their resources use and significantly increase their perennials farm returns.

- Appropriate combination of land, water, labour and capital resources for producing organic perennial crops combined with the other conventional perennial crops in RNS is very important and should be well designed and applied. 


\section{References}

Adam, A. N. (2008). Organic Agriculture in Sudan: East Africa Organic Conference Organic Agriculture in Sudan, Ministry of Agriculture and Forest, 2006 Khartoum: Sudan.

Ahmed, E.A. (2004). Economics of Faba bean Production and Marketing in the River Nile State: A Case study of Elddamer District: M. Sc. dissertation, Department of Agricultural Economics, University of Khartoum, Khartoum:

Sudan.

Ahmed, E.A. (2009). Economic Aspects and Water Use in Elzeidab and Elketiab Public Irrigated Schemes of the River Nile State. PhD dissertation, University of Khartoum, Khartoum:

Sudan.

Alviola, P. A. and Capps Jr., 0. (2010). Household demand analysis of organic and conventional fluid milk in the United States based on the 2004 Nielsen Homescan panel. Agribusiness 26 (3): 369-388.

Babiker, E. A. (2003). Organic Agriculture in Sudan and Its Impact on Rural Development: Paper prepared and presented in The Arab conference for Organic Agriculture in Tunisia, from 27-28 September 2003.

Badgley, C.; Moghtader, J.; Quintero, E.; Zakem, E.; Chappell, J.; Avils-Vzquez, K.; Samulon, A. and Perfecto, I. (2007). Organic Agriculture and the Global Food Supply: Renewable Agriculture and Food Systems, 22(2): 86-108.

Chang, C.H.; Hooker, N. H.; Jones, E. and Sam, A. (2010). Organic and conventional milk purchase behaviors in Central Ohio. Agribusiness, 27 (3): 311-326.
Doll, J.P. and Orazem, F. (1984). Production Economics: Theory with Applications. 2nd Edn., ISBN-10: 0894647695, pp: 470. Krieger Publishing Company.

Elsir, A.; Idris, M. and Faki, H. H. (2004). Irrigated Benchmark Site Project for Sudan. Plan of work presented for Agricultural Research Corporation (ARC). Wad Madani: Sudan.

Taher, F. (2003). Organic Agriculture in NENA Region: Paper prepared and presented in The Arab conference for Organic Agriculture in Tunisia, from 2728 September 2003.

Ijami, A. A. (1994). Efficiency and equity Effects of Market Access on Agricultural productivity in Sudan: A Case study Small Holder along the River Nile. Ph.D. dissertation, Hohenhim, University of Hohenhim, Germany.

Lim, L. C. (2007). Organic Agriculture and Food Security In Africa: Can Africa Feed Itself? Paper presented at Organic Agriculture and Food Security In Africa conference, Oslo, Norway, 6-8 June 2007.

\section{Organic Consumer Organization} (OCO) (2008). Organic Farming Offers Beginners a Viable Path into Agriculture: Center for Rural Affairs. Finland: Organic Consumers Association. Retrieved on January 2008 from: http://www.organicconsumers.org/articles/article_9613.cfm

Saitone, T. L. and Sexton, R. J. (2010). Impacts of minimum quality standards imposed through marketing orders or related producer organizations. Canadian Journal of Agricultural Economics 92: 164-80. 
Stan, C. (2008). Organic agriculture is not enough: we must replace annual with perennial crops. Retrieved on 2008 from: http://unityaotearoa. blogspot.com/2008/07/organic-agriculture-is-not-enough-we.html

Stonehouse, P. (2000). Economics of organic farming: Extracted from COG's Organic Field Crop Handbook, University of Guelph. 


\section{About the authors}

Dr. Elgilany Ahmed is a Visiting Senior Lecturer and Assistant Professor at Universiti Utara Malaysia, School of Economics, Finance and Banking, College of Business. He worked as a Socio-economic Researcher at Agricultural Economics and Policy Research Center of Agricultural Research Corporation (ARC). Conducting numerous socioeconomic research programs including different aspects pertaining with socioeconomic activities such as assessment and mapping of poverty, food security situation, agricultural policies, agricultural finance, environmental economics, resources use optimization, evaluation of on-farm irrigation water use efficiency and others by applying relevant analysis techniques and models including suitable software program such as GAMS, CROPWAT4, Stochastic Frontier and other computer software programs.

Professor Hamid H. M. Faki is currently a Freelance Professor and National Expert for Ministry of Agriculture and Forestry, Sudan. He earned his Ph.D. degree from Universitate of Hohanhiem in Germany. Professor Faki worked at various international organizations such as ICARDA and WFP. He carried out numerous research projects pertaining to agricultural economics, food security, poverty reduction, development and planning and socioeconomic studies. Furthermore, he is a supervisor for large a number of students. 